\title{
Cytomegalovirus (CMV) genotype in allogeneic hematopoietic stem cell transplantation
}

\author{
Débora C Dieamant ${ }^{1 *}$, Sandra HA Bonon ${ }^{1}$, Renata MB Peres ${ }^{1}$, Claudia RC Costa', Dúlcinéia M Albuquerque, \\ Eliana CM Miranda ${ }^{2}$, Francisco JP Aranha², Gislaine Oliveira-Duarte², Virginio CA Fernandes², Carmino A De Souza², \\ Sandra CB Costa ${ }^{1}$ and Afonso C Vigorito ${ }^{2}$
}

\begin{abstract}
Background: Based on sequence variation in the UL55 gene that encodes glycoprotein B $(g B)$, human cytomegalovirus (CMV) can be classified into four $g B$ genotypes. Previous studies have suggested an association between CMV gB genotype and clinical outcome in patients who underwent an allogeneic hematopoietic stem cell transplant (HSCT). The goals of this study were identify patients with active infection caused by CMV in recipients of HSCT; determine the prevalence of CMV genotypes in the study group; correlate genotype with CMV disease, acute GVHD and overall survival.
\end{abstract}

Methods: The diagnosis of active CMV infection after allogeneic HSCT was detected by antigenemia (AGM) and/or nested-PCR (N-PCR). Positive samples from patients with active CMV infection were submitted to genotyping using N-PCR to amplify a region of UL55, followed by restriction analysis based on Hinfl and Rsal digestion. Real-time PCR (qPCR) was used to determine the viral load during active CMV infection and antiviral treatment.

Results: Sixty-three allogeneic HSCT recipients were prospectively evaluated; 49/63 (78\%) patients were infected with CMV genotypes - gB1 19/49 (39\%), gB2 17/49 (35\%), gB3 3/49 (6\%), gB4 7/49 (14\%) - and 3 (6\%) had mixed CMV genotypes $(\mathrm{gB} 1+\mathrm{gB} 3, \mathrm{gB} 1+\mathrm{gB} 4$ and $\mathrm{gB} 2+\mathrm{gB} 4)$. Characterized by gastrointestinal disease, CMV disease occurred in 3/49 (6.1\%) patients, who had CMV gB3 genotype. These gB3 genotype patients presented an increasing AGM number, mean $125( \pm 250)(P=0.70)$, and $\mathrm{qPCR}$ copies $/ \mathrm{ml}$, mean 37938 (SD \pm 50542) $(P=0.03)$, during antiviral treatment, when compared with other CMV genotypes. According to CMV genotypes, stratified overall survival was 55\% for gB1, 43\% for gB2; 0\% for gB3 and 57\% for gB4 $(P=0.03)$.

Conclusions: One of the restrictions of the presented study was the low number of CMV gB sub-cohorts). However, we demonstrated that the frequency of active CMV infection in this HSCT population was high, and the most prevalent genotype in these patients with active CMV infection was gB1 and gB2 genotype (74\%). In Brazil, $\mathrm{HSCT}$ recipients seem to carry mainly gB1 and gB2 CMV genotype.

Keywords: CMV genotyping, Nested-PCR, Antigenemia, GVHD, qPCR, RFLP

\section{Background}

Cytomegalovirus (CMV) remains the most important cause of serious viral infections in allogeneic hematopoietic stem cell transplant (HSCT) recipients [1]. CMV glycoprotein B (gB) is the major CMV envelope glycoprotein and it is encoded by UL55 gene. CMV gB has been implicated in host cell entry, cell-to-cell viral

\footnotetext{
* Correspondence: ddieamant@hotmail.com

${ }^{1}$ Department of Clinical Medicine, Faculty of Medical Sciences, University of Campinas, Rua Vital Brazil, 251, ZIP Code: 13083-888 Campinas, SP, Brazil Full list of author information is available at the end of the article
}

transmission and fusion of infected cells [2-4]. Chou and Dennison (1991) devised a method of CMV genotyping based on UL55 gene nucleotide sequence that encodes a variable region encompassing the protease cleavage site. They found that there were HinfI and RsaI restriction sites between nucleotides 1344 and 1440. Amplification of this region, using polymerase chain reaction (PCR) followed by restriction analysis, demonstrated the existence of four different gB genotypes [5]. Since gB has been implicated in host cell penetration, it is possible that four types differ with respect to tissue tropism and

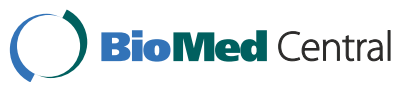


virulence. Many studies have attempted to find a correlation between gB genotype and the occurrence of CMVassociated disease in immunocompromised patients; however, it remains unclear whether certain gB genotypes are associated with an increased frequency of disease [6]. There are few references about functional differences that may exist among various CMV strains. It was reported that the existence of CMV variants played an important role in the pathogenesis of diseases, as these variants affected several genes that might be responsible for different diseases related to active CMV infection [7-10]. Recently, comparative sequence studies have been used to define the extent of interstrain variation in selected coding regions of the CMV genome. Clinical CMV isolates were found to adopt one of four gB sequence configurations at certain variable loci, and a genotyping scheme was proposed [11-13]. Although gB genotypes display significant amino acid variations in their variable domains, including changes that affect glycosylation sites, the functional consequences of these variations have not yet been explored [14-24].

This study aimed to prospectively analyze gB gene of CMV in allogeneic hematopoietic stem cell transplant (HSCT) recipients with human active CMV infection to determine the distribution of $\mathrm{gB}$ genotypes and their possible impact on overall survival, acute GVHD and CMV disease.

\section{Methods}

\section{Patients and samples}

This study comprised 63 adult patients with malignant and nonmalignant hematological diseases, who underwent a myeloablative or nonmyeloablative allogeneic HSCT at the Hematopoietic Stem Cell Transplantation Unit of the University of Campinas Teaching Hospital, with related or not related HLA identical donors and graft source from bone marrow or peripheral blood. The blood products used were neither screened for CMV antibody nor filtered to depleted leukocytes, although all had been irradiated. The conditioning regimens and GVHD prophylaxis were selected according to ongoing protocols at the University Hospital. These patients were prospectively monitored for active CMV infection from March 2007 to May 2010, using antigenemia (AGM) assay, nested-polymerase chain reaction (N-PCR) in leukocytes, and real-time polymerase chain reaction (qPCR). Patients with active CMV infection results were treated with preemptive ganciclovir. CMV genotypes of all positive patients were obtained by N-PCR and confirmed by sequencing, using primers from the glycoprotein $\mathrm{B}(\mathrm{gB})$ region of CMV (UL55) and restriction enzyme analysis (RFLP) with HinfI and RsaI enzymes. Real-time polymerase chain reaction (qPCR) assay was used to quantify the CMV load during active CMV infection and antiviral preemptive treatment. The protocol was designed in accordance with the requirements for research involving human subjects in Brazil and approved by the Institutional Review Board. Informed consent was obtained from all patients. Clinical characteristics of the study subjects are summarized in Table 1 .

The study was approved by the National Research Ethics (CONEP) of Brazil (680/2006).

\section{Definitions}

Active CMV infection was defined based on at least one of the following criteria: [1] one or more positive cells in the AGM assay, and [2] two or more consecutive positive N-PCR results. For the diagnosis of CMV disease, the active infection had to be accompanied by clinical symptoms and histopathological identification of CMV [25]. Recurrence of CMV infection was defined as active CMV infection occurring after negative N-PCR and/or AGM assays, following treatment of the initial episode of infection. Late active CMV infections and diseases were defined as those occurring more than 100 days after transplant.

\section{Antigenemia assay}

AGM assay was done at least once a week after engraftment, according to Bonon et al., 2005, with some modifications. EDTA-treated blood samples were fractionated by erythrocyte lyses. Granulocytes were then centrifuged to prepare cytospin slides $\left(2 \times 10^{5}\right.$ granulocytes per slide). After air-drying and fixing the slides in formaldehyde, they were immunostained using the well-defined $\mathrm{C} 10 / \mathrm{C} 11$ antibody cocktail to detect the CMV lower matrix phosphoprotein (pp65), an early antigen in virus replication, which is abundantly present in antigen-positive polymorphonuclear cells. The CMV Brite ${ }^{\text {tm }}$ Turbo Kit (Iq Products) is a rapid new version of the first FDA registered immunofluorescence antigenemia kit for in vitro CMV diagnosis. Slides were made in duplicate [26].

\section{Nested polymerase chain reaction (N-PCR)}

CMV DNA in blood specimens was detected by nested PCR using the primers described by Demmler et al. and Shibata et al. (1988). Briefly, leukocytes remaining from the CMV antigenemia assay were lysed and the DNA was precipitated. The primers were selected from the MIE region of CMV-AD169. The size of the PCR amplification products was 159 base pairs. The same protocol was used to amplify the human b-globin gene sequence to guarantee the quality of the extracted DNA $[27,28]$.

\section{Cytomegalovirus viral load assay Real-time $P C R$}

PCR primer and probe sequences were selected from the US17 region of CMV AD169. The real-time protocol 
Table 1 Patient and transplant characteristics

\begin{tabular}{|c|c|}
\hline Characteristics & $n=63$ \\
\hline Patient age, median (range), y & $42(16-65)$ \\
\hline \multicolumn{2}{|l|}{ Diagnosis at transplant, no. (\%) } \\
\hline \multicolumn{2}{|l|}{ Malignant diseases } \\
\hline Acute myeloid leukemia & $23(36.5 \%)$ \\
\hline Chronic myeloid leukemia & $9(14.3 \%)$ \\
\hline Acute lymphoblastic leukemia & $9(14.3 \%)$ \\
\hline Chronic lymphocytic leukemia & $4(6.3 \%)$ \\
\hline Multiple myeloma & $2(3.2 \%)$ \\
\hline Non-Hodgkin lymphoma & $3(4.8 \%)$ \\
\hline Hodgkin lymphoma & $2(3.2 \%)$ \\
\hline Myelodysplastic syndrome & $4(6.3 \%)$ \\
\hline \multicolumn{2}{|l|}{ Non-malignant diseases } \\
\hline Severe aplastic anemia & $4(6.3 \%)$ \\
\hline Paroxysmal nocturnal hemoglobinuria & $3(4.8 \%)$ \\
\hline Donor age, median (range), y & $39(6-65)$ \\
\hline \multicolumn{2}{|l|}{ Patient gender (donor/recipient), n. (\%) } \\
\hline Male/male & $23(36.5 \%)$ \\
\hline Male/female & $10(15.9 \%)$ \\
\hline Female/male & $13(20.6 \%)$ \\
\hline Female/female & $17(27 \%)$ \\
\hline \multicolumn{2}{|l|}{ Donor type, no. (\%) } \\
\hline HLA-identical related & $61(96.8 \%)$ \\
\hline HLA-matched unrelated & $2(3.2 \%)$ \\
\hline \multicolumn{2}{|l|}{ Conditioning regimen, no. (\%) } \\
\hline High dose & $46(73 \%)$ \\
\hline Low dose & 17 (27\%) \\
\hline \multicolumn{2}{|l|}{ Source of stem cells, no. (\%) } \\
\hline Bone marrow & $23(36.5 \%)$ \\
\hline Mobilized blood & $40(63.5 \%)$ \\
\hline \multicolumn{2}{|l|}{ GVHD prophylaxis, no. (\%) } \\
\hline Cyclosporine plus methotrexate & $49(77.7 \%)$ \\
\hline Cyclosporine plus mycophenolate mofetil & $14(22.3 \%)$ \\
\hline Acute GVHD, no. (\%) & $17(27 \%)$ \\
\hline Grade 0-I & $46(73 \%)$ \\
\hline Grade II-IV & 17 (27\%) \\
\hline \multicolumn{2}{|l|}{ Donor/recipient CMV serologic status, $\mathrm{n}^{\circ}(\%)$} \\
\hline $\operatorname{lgG}+/ \operatorname{lgG}+$ & $55(87.2 \%)$ \\
\hline $\lg G+/ \lg G-$ & $3(4.8 \%)$ \\
\hline $\lg G-/ \lg G-$ & $2(3.2 \%)$ \\
\hline lgG-/igG+ & $2(3.2 \%)$ \\
\hline Not determined & $1(1.6 \%)$ \\
\hline
\end{tabular}

$\overline{G V D H}$ graft-versus-host disease, CMV cytomegalovirus. was according to Peres et al., 2010. The forward and reverse CMV primers were 5' GAAGGTGCAGGTGCCC TG 3' and 5' GTGTCGACGAACGACGTACG 3', respectively. The Taq Man probe selected between both primers was fluorescence labeled with 6-carboxyfluorescein at the $5^{\prime}$ end as the reporter dye and 6- carboxytetramethylrhodamine at the $3^{\prime}$ end as the quencher (5'FAM ACGGTGCTGTAGACCCGCATACAAA TAMRA3').

A search of databases indicated that neither the primers nor the probes shared significant homology with any known nucleotide sequence except of CMV. The real-time PCR was performed with a mixture containing: $3 \mathrm{mM} \mathrm{MgCl} 2 ; 10 \mu \mathrm{M}$ dATP, dCTP, dGTP, dTTP; $5 \mathrm{U} / \mu \mathrm{l}$ of Platinum Taq (Invitrogen), $60 \mathrm{ng}$ DNA templates, $150 \mathrm{nM}$ of forward and reverse primers (CMVUS17FCMVUS17R for CMV detection) and $2 \mu \mathrm{M}$ of the specific Taq Man CMV probe (PE Applied Biosystems). The single PCR was performed in 96-well microliter plates under the following conditions: 1 cycle at $50^{\circ} \mathrm{C}$ for 2 minutes, $95^{\circ} \mathrm{C}$ for 10 minutes and 45 cycles at $95^{\circ} \mathrm{C}$ for 15 seconds and $60^{\circ} \mathrm{C}$ for 1 minute. The $\beta$-actin gene amplification was performed under the same PCR conditions described above for the reaction control, using $2 \mu \mathrm{M} ß$-actin probe (FAM ${ }^{\mathrm{m}}$ Probe), $3 \mu \mathrm{M}$ ß-actin forward primer, and $3 \mu \mathrm{M} ß$-actin reverse primer (TaqMan ${ }^{\circ}$ $ß$-actin detection reagents - Applied Biosystems) [29].

\section{Amplification of $\mathrm{gB}$ gene by nested-PCR}

Oligonucleotide primers used for PCR amplification were chosen in a region of high sequence variability in the CMV gB gene, as previously published by Chou and Dennison (1991), and were synthesized commercially (Invitrogen, by Life Technologies, Brazil). The first and the second rounds of amplification were carried out in a total volume of $50 \mu \mathrm{l}$, using $200 \mathrm{ng}$ DNA extract (1st) and $1 \mu \mathrm{l} \mathrm{PCR} \mathrm{product} \mathrm{(2nd)} \mathrm{and} 49 \mu \mathrm{l} \mathrm{PCR} \mathrm{mix}(10 \mathrm{mM}$

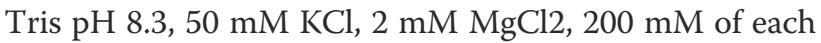
dNTPs, $1.25 \mathrm{U}$ of recombinant Taq DNA polymerase and $0.4 \mathrm{mM}$ of each primer (Invitrogen, by Life Technologies, Brazil). After amplification, $5 \mu \mathrm{l}$ of the amplified product were electrophoresed on $2 \%$ agarose gel (GibcoBRL, Grand Island, NY) containing ethidium bromide, and the gel was photographed under UV illumination. The AD169 strain was used as a positive control; an uninfected DNA sample or water was used as a negative control [5].

\section{CMV gB genotyping with PCR-RFLP analysis and sequence analyses}

Approximately $10 \mu \mathrm{l}$ of nested PCR product were digested at $37^{\circ} \mathrm{C}$ overnight, using $1 \mathrm{U}$ of the restriction enzymes, Rsa I and Hinf I (Gibco-BRL). Sequences were analyzed on a $2 \%$ agarose 1000 gel (Gibco-BRL). The four types of $\mathrm{gB}$ were distinguished by their different patterns of fragment lengths, as described [5]. 
To determine the sequences of the CMV gB genotype samples, the PCR products were purified using the PCR purification kit (Quiagen) and subcloned into the pGEM$\mathrm{T}$ vector (Promega, Madison, WI, USA). Sequences were obtained using the ABI 310 genetic analyser (Applied Biosystems, Bedford, MA, USA) with proper primers, and they were aligned with known CMV variants in GenBank afterward. The sequences of gB1, gB2, gB3 and gB4 were very similar to GenBank M60927, M60931, M60930 and M60926 respectively.

\section{Statistical analysis}

The descriptive analysis summarized patient sociodemographic characteristics, as well as transplant, GVHD and CMV serologic status of donors and receptors. The Fisher's and Kruskal-Wallis tests were applied for categorical and continuous variables, respectively. The Kaplan-Meier method was used to estimate overall survival. Stratified overall survival, according to CMV genotypes, was compared with the log-rank test. Death by any cause was considered as event. The gB1 + gB3 mixture was clustered into genotype gB3 for statistical purpose, since these strains had the same behavior in the study.

The other two mixtures detected, $\mathrm{gB} 1+\mathrm{gB} 4$ and $\mathrm{gB} 2+$ gB4, were not grouped, as they did not identify any pattern of behavior. The $p$-value $<0.05$ was considered significant. The statistical analyses were performed using the software SPSS 14 (Statistical Package for Social Sciences).

\section{Results}

Among the 63 patients, 49 (78\%) had active CMV infection detected by AGM and/or N-PCR tests. Active CMV infection occurred within a median time of 38 days (1-150) after the transplant. The median time to detect active CMV infection by AGM and N-PCR was 46 (14-150) and 34 days (1-140), respectively. The incidence of active CMV infections is summarized in Table 2.

\section{CMV gB genotype}

Forty-nine patients with active CMV infection were submitted to CMV genotyping using RFLP. Nineteen out of 49 (39\%) recipients had gB1 genotype; 17 out of 49 (35\%), gB2; 3 out of 49 (6\%), gB3; and 7 out of 49 (14\%), gB4. There were three patients $(6 \%)$ who had a combination of two different $\mathrm{CMV}$ genotypes $(\mathrm{gB} 1+\mathrm{gB} 3, \mathrm{gB} 1+\mathrm{gB} 4$ and $\mathrm{gB} 2+\mathrm{gB} 4)$.

Eight samples (two with gB1, two with gB2, two with gB3 and two with gB4) and three mixed CMV genotype samples were sequenced. The patients' CMV sequences were $98-99 \%$ identical to CMV sequences in GenBank when compared.
Table 2 Incidence of active CMV infection

\begin{tabular}{lc}
\hline Patients & $\mathbf{n = 6 3}$ \\
\hline Positive N-PCR and/or AGM, n (\%) & $49(78 \%)$ \\
Median time, days (range) & $38(1-150)$ \\
Positive N-PCR, n (\%) & $49(78 \%)$ \\
Median time, days (range) & $34(1-140)$ \\
Positive AGM, n (\%) & $37(58.7 \%)$ \\
Median time, days (range) & $46(14-150)$ \\
\hline
\end{tabular}

$\mathrm{N}-\mathrm{PCR}$ nested polymerase chain reaction, AGM antigenemia.

\section{CMV disease, acute GVHD and gB genotype}

Among the 49 patients who had active CMV infection, three (6\%) developed CMV disease manifested as gastrointestinal disease, two had $\mathrm{gB} 3$ and one had a mixture of gB1 + gB3 strains.

The active CMV infection recurrence detected by HCMV antigenemia and/or nested PCR occurred in 9 out of $49(18 \%)$ patients within a median of 92 days (61-138), with the same infecting strain caused by the first active CMV infection. The recurrence occurred in 1 out of 9 (11\%) cases with gB1, in 1 out of $9(11 \%)$ with gB2, in 3 out of $9(33 \%)$ with gB3, and in 4 out of $9(44 \%)$ with gB4.

Seventeen out of 49 (35\%) patients with CMV active infection developed grade II-IV acute GVHD. Among the patients with acute GVHD, 12 out of 17 (70.6\%) had acute GVHD before diagnosis of active CMV infection; however, 5 out of $17(29.4 \%)$ patients had active CMV infection before acute GVHD. Diagnosis of active CMV infection occurred within a median of 20 days [6-35] after diagnosis of acute GVHD, and acute GVHD occurred within a median of 45 days (27-59) after active CMV infection. The frequency of II-IV acute GVHD, according to CMV gB genotype, showed that 8 out of $19 \mathrm{gB} 1 \mathrm{pa}-$ tients (42\%), 1 out of $17 \mathrm{gB} 2$ patients (6\%), 3 out of $7 \mathrm{gB} 4$ patients (43\%) had aGVHD, and all $4 \mathrm{gB} 3$ patients, including the mixture $\mathrm{gB} 1+\mathrm{gB} 3$, had aGVHD $(P=0.008)$.

\section{DNA load at onset of active CMV infection and during preemptive treatment monitoring}

At the active CMV infection onset, gB3 genotype presented the highest number of AGM-positive, mean 251 (SD \pm 499 ), and $\mathrm{gB} 2$ the highest $\mathrm{qPCR}$ copies/ml, mean 1733 (SD \pm 6272). However, the difference between the four genotypes for either AGM or qPCR was not significant $(\mathrm{AGM}-p$-value $=0.73 ; \mathrm{qPCR}-p$-value $=0.13)$. These results are summarized in Table 3.

In spite of preemptive treatment for active CMV infection, three out of four gB3 patients developed gastrointestinal disease. In two out of those three patients, CMV replication occurred after onset of grade II-IV acute GVHD. Interesting, during preemptive treatment, these gB3 genotype patients presented an increasing AGM number, mean $125( \pm 250)(p=0.70)$, and qPCR 
Table 3 Results of AGM and viral load by qPCR at active CMV infection and during preemptive treatment monitoring

\begin{tabular}{|c|c|c|c|c|c|c|c|}
\hline \multicolumn{2}{|c|}{ Genotypes } & \multirow{2}{*}{$\frac{\text { Median }}{3}$} & \multirow{2}{*}{$\begin{array}{c}\text { Range } \\
0-38\end{array}$} & \multirow{2}{*}{$\frac{\text { Mean }}{8}$} & \multirow{2}{*}{$\begin{array}{c}\text { SD } \\
\pm 12\end{array}$} & \multirow{2}{*}{$\frac{\text { Mean* }^{*}}{-}$} & \multirow{2}{*}{$\begin{array}{c}\text { SD } \\
-\end{array}$} \\
\hline gB1 & AGM (n cells) & & & & & & \\
\hline & qPCR (copies/ml) & 92 & $15-804$ & 388 & \pm 864 & 2.05 & \pm 0.68 \\
\hline \multirow[t]{2}{*}{ gB2 } & AGM (n cells) & 3 & $0-10$ & 3 & \pm 3 & - & - \\
\hline & qPCR (copies/ml) & 23 & $3-26012$ & 1733 & \pm 6272 & 1.72 & \pm 1.07 \\
\hline \multirow[t]{2}{*}{ gB3 } & AGM (n cells) & 2 & $1-1000$ & 251 & \pm 499 & - & - \\
\hline & qPCR (copies/ml) & 12 & $3-753$ & 195 & \pm 372 & 1.37 & \pm 1.05 \\
\hline \multirow[t]{2}{*}{ gB4 } & AGM (n cells) & 1 & $0-70$ & 11 & \pm 26 & - & - \\
\hline & qPCR (copies/ml) & 351 & $13-2283$ & 675 & \pm 892 & 2.32 & \pm 0.84 \\
\hline
\end{tabular}

AGM antigenemia, $q P C R$ real-time polymerase chain reaction.

${ }^{*}$ Mean qPCR in logarithm base $10 ; \mathrm{n}=$ number of $p$ p65 CMV positive cells $/ 2 \times 10^{5} ; \mathrm{SD}=$ standard deviation; $\mathrm{AGM}-p$-value $=0.73 ; \mathrm{qPCR}-\mathrm{p}$-value $=0.13$ (kruskal-WallisTest).

copies/ml, mean 37938 (SD \pm 50542), when compared with other CMV genotypes $(p=0.03)$. These results are presented in Table 4 and Figure 1.

\section{Overall survival and CMV gB genotype}

Among the 49 patients with active CMV infection, 25 (51\%) died. The distribution of causes of death were as follows: relapse, 10 out of 25 (40\%); bacterial or fungal infection, 10 out of 25 (40\%); GVHD, 2 out of 25 (8\%); cardiac toxicity, 1 out of 25 (4\%); pulmonary hemorrhage, 1 out of 25 (4\%); CMV disease, 1 out of 25 (4\%).

After a median follow-up of 17 months [1-52], the overall survival for patients with active CMV infection was $45 \%$ (95\% CI 39-61\%); whereas the stratified overall survival, according to CMV genotypes, was 55\% for gB1, $43 \%$ for gB2; $0 \%$ for gB3 and $57 \%$ for gB4 $(p=0.03)$, as shown in Figures 2 and 3.

\section{Discussion}

In this cohort of Brazilians patients with active CMV infection, the most frequent genotypes were gB1 and gB2 (74\%). Moreover, all patients who had CMV gastrointestinal disease, higher viral load during preemptive antiviral treatment, acute GVHD grade II-IV and worse survival were gB3 genotype.

The high incidence of active CMV infection detected either by N-PCR or AGM in our population was comparable to prior reports and they were equally effective for diagnosis of active infection and disease [26,30-32]. Although the proportion of CMV seronegative donors or recipients has been small, almost all positive N-PCR and AGM results were from CMV seropositive patients.

According to previously described CMV envelope glycoprotein genotypes, we were able to confirm that CMV gB genotyping could reliably identify one of four established gB genotypes, using two restriction endonucleases - HinfI and RSAI - to digest the PCR-amplified variable region of UL55, encoding the protease cleavage site $[5,33]$. GB1 and gB2 were the most frequent genotypes in this study, and they occurred in similar proportions (39\% and 35\%, respectively). These results are in line with other studies, including one from our group performed in a Brazilian pediatric renal and hematopoietic stem cell transplantation cohort [7,34-37], but not with a report from Chinese HSCT patients, where gB1 and gB3 were the prevalent genotypes [38,39]. Furthermore, in our population, the

Table 4 Results of AGM and viral load by qPCR in the monitoring of preemptive antiviral treatment stratified by genotypes

\begin{tabular}{|c|c|c|c|c|c|c|c|}
\hline \multicolumn{2}{|c|}{ Genotypes } & \multirow{2}{*}{$\begin{array}{c}\text { Median } \\
0\end{array}$} & \multirow{2}{*}{$\begin{array}{c}\text { Range } \\
0-200\end{array}$} & \multirow{2}{*}{$\frac{\text { Mean }}{12}$} & \multirow{2}{*}{$\begin{array}{c}\text { SD } \\
\pm 46\end{array}$} & \multirow{2}{*}{$\frac{\text { Mean* }}{-}$} & \multirow{2}{*}{$\begin{array}{c}\text { SD } \\
-\end{array}$} \\
\hline gB1 & AGM (n cells) & & & & & & \\
\hline & qPCR (copies/ml) & 261 & $15-8358$ & 1247 & \pm 2352 & 2.51 & \pm 0.76 \\
\hline \multirow[t]{2}{*}{ gB2 } & AGM ( $n$ cells) & 0 & $0-500$ & 63 & \pm 165 & - & - \\
\hline & qPCR (copies/ml) & 359 & 5-26012 & 4088 & \pm 8537 & 2.45 & \pm 1.16 \\
\hline \multirow[t]{2}{*}{ gB3 } & AGM (n cells) & 0 & $0-500$ & 125 & \pm 250 & - & - \\
\hline & qPCR (copies/ml) & 20751 & $115-110136$ & 37938 & \pm 50542 & 3.86 & \pm 1.31 \\
\hline \multirow[t]{2}{*}{ gB4 } & AGM (n cells) & 0 & $0-7$ & 1 & \pm 3 & - & - \\
\hline & qPCR (copies/ml) & 4690 & 46-73084 & 15758 & \pm 26024 & 3.41 & \pm 1.23 \\
\hline
\end{tabular}

AGM antigenemia, $q P C R$ real-time polymerase chain reaction.

${ }^{*}$ Mean qPCR transformed in logarithmic base $10 ; \mathrm{n}=$ number of $p p 65 \mathrm{CMV}$ positive cells $/ 2 \times 10^{5} ; \mathrm{SD}=$ standard deviation. Antigenemia $-P$-value $=0.70$; qPCR - P-value $=0.03$ (kruskal-WallisTest). 


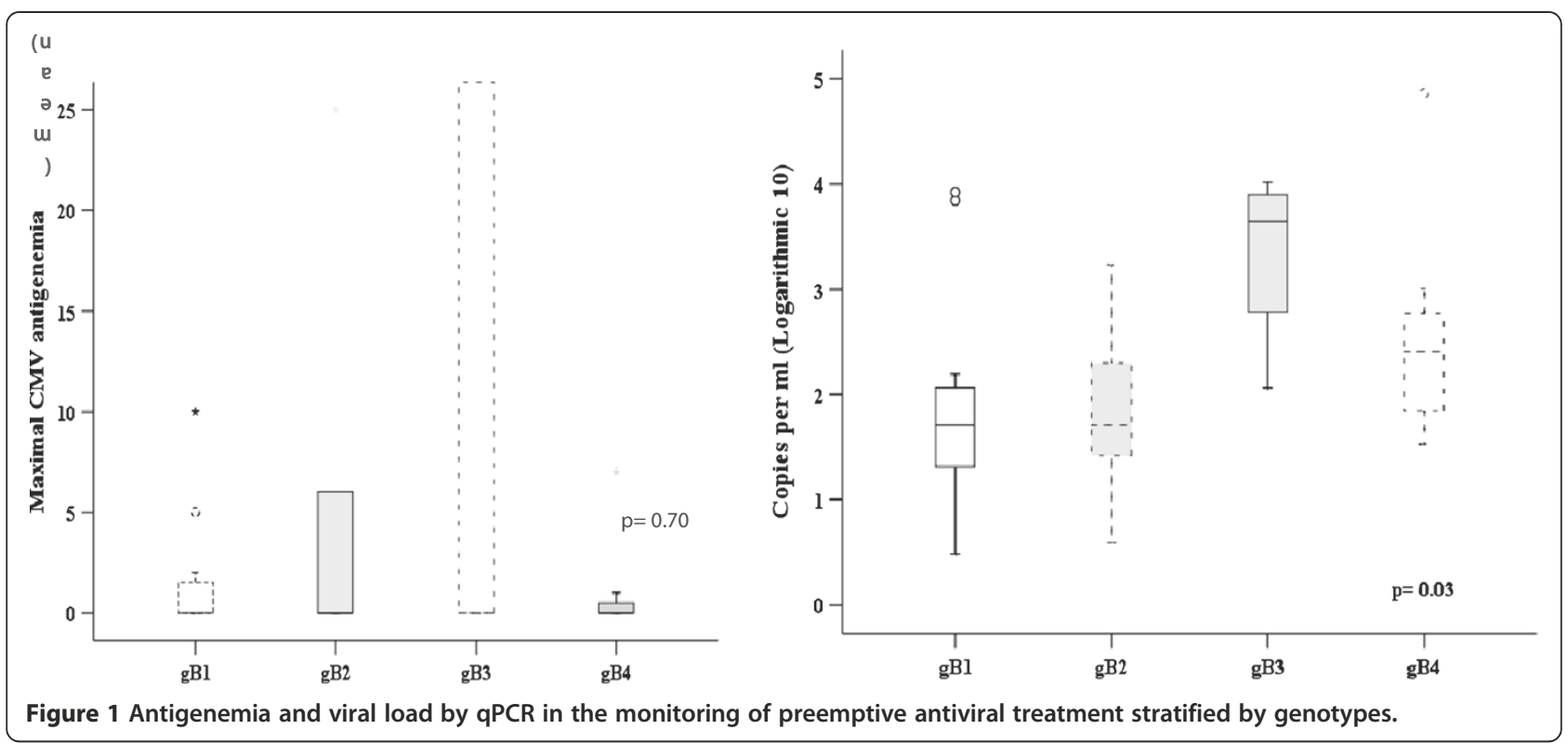

proportion of mixed genotypes was rare (6\%), that is comparable to recent reports which showed ranges from $5 \%$ to $25 \%[6,38,40]$.

CMV gB genotype may be an important determinant of viral virulence because gB has been implicated in several essential steps in CMV pathogenesis, such as virus entry, cell fusion, and cell-to-cell spread. The virulence of different CMV strains may be an important factor in the occurrence of CMV disease because of genetic variation in genes that are involved in host cell penetration, tissue tropism, or replication, and polymorphism in the viral genome may play an important role [40-42].

Outcomes of different CMV genotypes with clinical manifestations are conflicting. CMV gB3 and gB4 were reported to be associated with myelosuppression in HSCT patients [35], gB3 with high incidence of pneumonitis [38], and gB1 with invasive disease in solid organ transplantation [36,38]. A recent Brazilian study involving AIDS

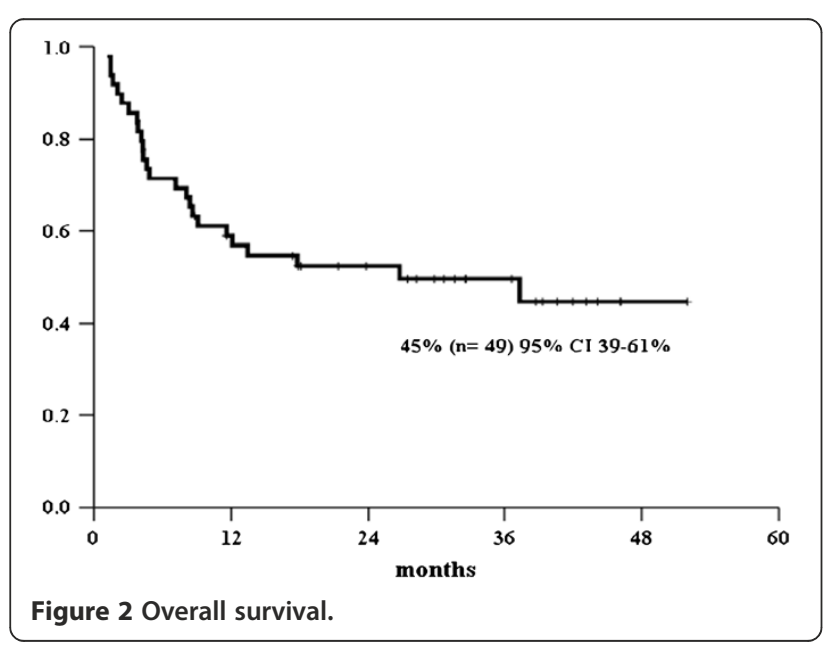

patients demonstrated that gB2 genotype was associated with worse prognosis [43]. In prior studies, mixed CMV genotypes were observed to be associated with a high prevalence of CMV disease in solid-organ transplant patients $[6,44,45]$, but in our study we did not find these results.

Neither cases of myelossupression and pneumonitis, nor a high prevalence of CMV disease in mixed CMV genotypes were seen in our data, but intriguing all cases of CMV disease were associated with the gastrointestinal tract, and all of them had genotype gB3. Hence, gB3 genotype might confer a specific virulence advantage for that genotype in our cohort. Although some associations have been described so far between a certain virus subtype and the development of individual disease these analyses were greatly complicated by the huge genomic

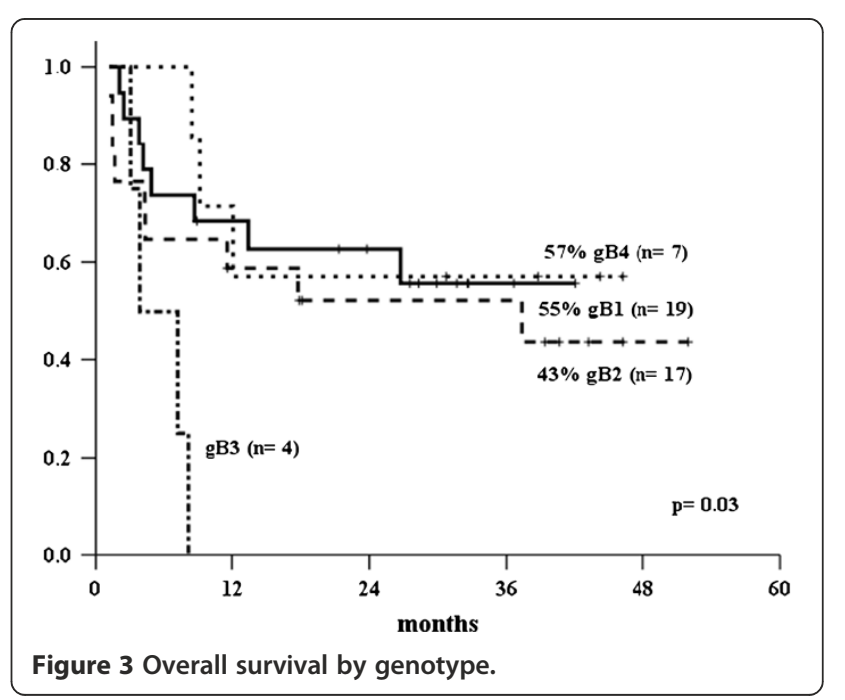


background of CMV, by the large variety of individual host-virus relations and by differences in the geographic or demographic subtype distribution [46].

Acute GVHD and CMV replication are pathogenetically associated. In this report, most patients had GVHD before the onset of CMV infection, confirming what several studies have already shown that acute GVHD and its treatment put patients at risk for CMV replication [43,47-49]. In contrast, the role of CMV replication as a cause of acute GVHD is controversial. One recent small study found no effect of CMV replication on subsequent development of acute GVHD [50]. Others demonstrated the reciprocal finding that patients are at significant risk of developing acute GVHD during CMV replication $[43,51]$.

Torok-Storb et al. [35] reported that CMV gB3 was associated with a reduced risk of GVHD in HSCT patients. Wu et al. [38] failed to demonstrate an association of B genotypes with GVHD. We found a different distribution of II-IV acute GVHD according to gB genotypes, and all gB3 genotypes were involved with acute GVHD, highlighting a possible association of that genotype with acute GVHD.

We observed that the mean load viral was higher in gB2 at the diagnosis; however, during the preemptive antiviral treatment, the viral load detected, either by qPCR and AGM, showed an increase in gB3 genotype. Clearly, genotype gB3 showed a different behavior when compared with other genotypes, leading to believe that this might be associated with a more severe and uncontrolled infection that caused all cases of gB3 gastrointestinal CMV disease and a worse survival in our population.

Perhaps, not gB3 genotype per se but its low frequency in the patient's cohort may be associated with bad outcome of the CMV infection. If this genotype is rare in this region, higher is the probability of primo infection in this population during the transplantation, that is associated with insufficient or delayed immune response, prolonged high level of virus replication and higher risk of CMV disease and related complications.

\section{Conclusion}

One of the restrictions of the presented study was the low number of CMV gB sub- cohorts). However, we demonstrated that the frequency of active CMV infection in this HSCT population was high and the most prevalent genotype in these patients with active CMV infection was gB1 and gB2 genotype (74\%). In Brazil, HSCT recipients seem to carry mainly gB1 and gB2 CMV genotype.

\section{Competing interests}

The authors declare that they have no competing interests.

\section{Authors' contribution}

ACV study design, collected data, analyzed data and wrote the paper; DCD study design, collected data, analyzed the data and wrote the paper; ECMM performed the statistical analysis; SHB, RMBP, CRCC, DMA updated the collected the data for the study; FJPA, GO-D, VCAF, CADS reviewed the manuscript; SCBC study design and reviewed the manuscript. All authors read and approved the final manuscript.

\section{Acknowledgment}

We are also very grateful to our patients for their participation in this trial and the medical staff for their collaborative efforts in the excellent care provided to patients and families.

This work was supported by Fundação de Amparo à Pesquisa do Estado de São Paulo (grant 07/52388-1).

\section{Author details}

${ }^{1}$ Department of Clinical Medicine, Faculty of Medical Sciences, University of Campinas, Rua Vital Brazil, 251, ZIP Code: 13083-888 Campinas, SP, Brazil.

${ }^{2}$ Hematopoietic Stem Cell Transplantation Unit of the University of Campinas Teaching Hospital, University of Campinas, Campinas, SP, Brazil.

Received: 8 August 2012 Accepted: 24 June 2013

Published: 10 July 2013

\section{References}

1. Allice T, Cerruti F, Pittaluga F, et al: Evalution of a novel real-time PCR system for cytomegalovirus DNA quantitation on whole blood and correlation with pp 65-antigen test in guiding pre-emptive antiviral treatment. J Virol Methods 2008, 148:9-16.

2. Cranage MP, Kouzarides T, Bankier AT, Satchwell S, Weston K, Tomlinson P, et al: Identification of the human cytomegalovirus glycoprotein $B$ gene and induction of neutralizing antibodies via its expression in recombinant vaccine virus. Eur Mol Biol Orgn J 1986, 5:3057-3063.

3. Navarro D, Paz P, Tugizov S, Topp K, La Vail J, Pereira L: Glycoprotein B of human cytomegalovirus promotes virion penetration into cells, transmission of infection from cell to cell, and fusion of infected cells. Virology 1993, 197:143-158.

4. Hopkins Jl, Fiander AN, Evans AS, Delchambre M, Gheysen K, Borysiewicz LK: Cytotoxic T cell immunity to human cytomegalovirus glycoprotein B. J Med Virol 1996, 49:124-131.

5. Chou SW, Dennison KM: Analysis of interstrain variation in cytomegalovirus glycoprotein B sequences encoding neutralizationrelated epitopes. J Infect Dis 1991, 163:1229-1234.

6. Sarcinella L, Mazzulli T, Willey B, et al: Cytomegalovirus glycoprotein B genotype does not correlate with outcomes in liver transplant patients. J Clin Virol 2002, 24:99-105.

7. Fries BC, Chou S, Boeckh M, et al: Frequency distribution of cytomegalovirus envelope glycoprotein genotypes in bone marrow transplant recipients. J Infect Dis 1994, 169:769-774.

8. Meyer-Koning U, Volgelberg C, Bongarts A, et al: Glycoprotein B genotype correlates whit cell tropism in vivo of human cytomegalovirus infection. J Med Virol 1998, 55:75-81.

9. Meyer-Koning $U$, Haberland $M$, von LD, et al: Intragenic vsriability of human cytomegalovirus glycoprotein B in clinical strains. J Infect Dis 1998, 177:1162-1669.

10. Sinzger C, Schmidt K, Knapp J, et al: Modification of human cytomegalovirus tropism through propagation in vitro is associated with changes in the viral genome. J Gen Virol 1999, 80:2867-2877.

11. Chou S: Comparative analysis of sequence variation in gp116 ang gp55 components of human cytomegalovirus. Virology 1992, 188:388-390.

12. Chou S: Molecular epidemiology of envelope glycoprotein $\mathrm{H}$ of human cytomegalovirus. J Infect Dis 1992, 166:604-607.

13. Pachl C, Probert WS, Hermsen KM, et al: The human cytomegalovirus strain Towne glycoprotein $\mathrm{H}$ gene encodes glycoprotein $\mathrm{p} 86$. Virology 1989, 169:418-426.

14. Britt WJ: Neutralizing antibodies detect a disulfide-linked glycoprotein complex within the envelope of human cytomegalovirus. Virology 1984 135:369-378.

15. Cranage MP, Kouzarides T, Bankier AT, et al: Identification of the cytomegalovirus glycoprotein B gene and induction of neutralizing antibodies via its expression in recombinabt vaccination vires. EMBO J 1987, 5:3063-6057.

16. Rasmusses L, Mullenax J, Nelson R, Merigan TC: Viral polypeptides detected by a complet-dependent neutralizing murine monoclonal antibody to human cytomegalovirus. J Virol 1985, 55:274-280. 
17. Kari B, Lussenhop N, Goertz R, Wabuke-Bunoti M, Radeke R, Gehrz R: Characterization of monoclonal antibodies reactive to several biochemically distinct human cytomegalovirus glycoprotein complexes. J Virol 1986, 60:345-352.

18. Banks T, Hou B, Kousoulas K, Spaete R, Pachl C, Pereira L: A major neutralizing domain maps within the carboxyl-terminal half of the cleaved cytomegalovirus B glycoprotein. J Gen Virol 1989, 70:979-985.

19. Britt WJ, Vugler L, Butfiloski EJ, Stephens EB: Cell surface expression of human cytomegalovirus (HCMV) gp55-116 (gB): use of HCMVrecombinant vaccinia virus-infected cells in analysis of the human neutralizing antibody response. J Virol 1990, 64:1079-1085.

20. Kniess N, Mach M, Fay J, Britt WJ: Distribution of linear antigenic sites on glycoprotein gp55 of human cytomegalovirus. J Virol 1991, 65:138-146.

21. Urban M, Britt W, Mach M: The dominant linear neutralizing antibodybiding site of glycoprotein gp86 of human cytomegalovirus. J Virol 1992, 66:1303-1311

22. Qadri I, Navarro D, Paz P, Pereira L: Assembly of conformation-dependent neutralizing domains on glycoprotein $B$ of human cytomegalovirus. J Gen Virol 1992, 73:2913-2921.

23. Basgoz N, Qadri I, Navarro D, et al: The amino terminus of human cytomegalovirus glycoprotein B contains epitopes that vary among strains. J Gen Virol 1992, 73:983-988.

24. Keay S, Merigan TC, Rasmussen L: Identification of cell surface receptors for the 86-kilodalton glycoprotein of cytomegalovirus. Proc Natl Acad SCl USA 1989, 86:10100-10103.

25. Ljungman P: Prevention and treatment of viral infections in stem cell transplant recipients. Br J Haematol 2002, 118:44-57.

26. Bonon SHA, Menoni SMF, Rossi CL, et al: Surveillance of cytomegalovirus infection in haematopoietic stem cell transplantation patients. J Infect 2005, 50:130-137.

27. Demmler GJ, Buffone GJ, Scimbor CM, May RA: Detection of cytomegalovirus in urine from newborns by using polymerase chain reaction DNA amplification. J Infect Dis 1988, 158:1177-1184.

28. Shibata D, Martin WJ, Appleman MD, Causey DM, Leedom JM, Arnheim N: Detection of cytomegalovirus DNA in peripheral blood of patients infected with human deficiency virus. J Infect Dis 1988, 158:1185-1192.

29. Peres RMB, Costa CRC, Andrade PD, Bonon SHA, Albuquerque DM, et al: Surveillance of active human cytomegalovirus infection in hematopoietic stem cell transplantation (HLA sibling identical donor): search for optimal cutoff value by real-time PCR. J Infect Dis 2010, 10:147-154.

30. Chakrabarti S, Mackinnon S, Chopra R, et al: High incidence of cytomegalovirus infection after nonmyeloablative stem cell transplantation: potential role of Campath-1H in delaying immune reconstitution. Blood 2002, 99:4357-4363.

31. Yakushiji $\mathrm{K}$, Gondo H, Kamezaki K, et al: Monitoring of cytomegalovirus reactivation after allogeneic stem cell transplantation: comparison of an antigenemia assay and quantitative real-time polymerase chain reaction. Bone Marrow Transplant 2002, 29:599-606.

32. Machado CM, Dulley FL, Vilas Boas LS, et al: CMV pneumonia in allogeneic BMT recipients undergoing early treatment or pre-emptive ganciclovir therapy. Bone Marrow Transplant 2000, 26:413-417.

33. Pignatelli S, Dal Monte P, Rossini G, Landini MP: Genetic polymorphisms among human cytomegalovirus (HCMV) wild-type strains. Rev Med Virol 2004, 14:383-410.

34. Dieamant DC, Bonon SHA, Prates LC, Belangelo VMS, Pontes ER, Costa SCB: Active human cytomegalovirus infection and glycoprotein $B$ genotypes in Brazilian pediatric renal or hematopoietic stem cell transplantation patients. Br J Microb 2010, 41:50-58.

35. Torok-Storb B, Boeckh M, Hoy C, et al: Association of specific cytomegalovirus genotypes with death from myelosuppression after marrow transplantation. Blood 1997, 90:2097-2102.

36. Nogueira E, Ozaki KS, Tomiyama H, et al: Clinical correlations of human cytomegalovirus strains and viral load in kidney transplant recipients. Int Immunopharmacol 2009, 9:26-31.

37. Humar A, Kumar D, Gilbert C, et al: Cytomegalovirus (CMV) glycoprotein B genotypes and response to viral therapy, in solid-organ-transplant recipients with CMV disease. J Infect Dis 2003, 188:581-584.

38. Wu X, Wang Y, Xu Y, Wu D, Sun A, Zhu Z, et al: Cytomegalovirus glycoprotein $B$ genotype in hematopoietic stem cell transplant patients from China. Biol Blood Marrow Transplant 2010, 16:647-652.
39. Wu KG, Hung MC, Chang YT, Chen CJ, Yang SP, Liu CY, Ho DMT, Chan YJ: Occurrence of human cytomegalovirus glycoprotein B genotypes in immunocompetent and immunosuppressed Taiwanese patients. Intervirology 2011, 54:196-201.

40. Coaquette A, Bourgeois A, Dirand C, et al: Mixed cytomegalovirus glycoprotein B genotypes in immunocompromised patients. Clin Infect Dis 2004, 39:155-161.

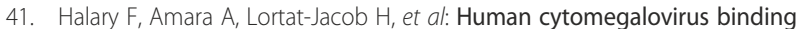
to DC-SING is required for dendritic cell infection and target cell trans-infection. Immunity 2002, 17:653-664.

42. Yu ZS, Zou CC, Zheng JY, Zhao ZY: Cytomegalovirus gB genotype and clinical features in Chinese infants with congenital infections. Intervirology 2006, 49:281-285.

43. Puchhammer-Stockl E, Gorzer I, Zoufaly A, et al: Emergence of multiple cytomegalovirus strains in blood and lung of lung transplant recipients. Transplantation 2006, 81:187-194.

44. Cunha AA, Aquino VH, Mariquela V, Nogueira ML, Figueiredo LT: Evaluation of glycoprotein B genotype and load of CMV infecting blood leukocytes on prognosis of AIDS patients. Rev Inst Med Trop São Paulo 2011, 53:82-88.

45. Manuel O, Asberg A, Pang X, Rollag H, Emery VC, Preiksaitis JK, Kumar D, Pescovitz MD, Bignamini AA, Hartmann A, Jaedine AG, Humar A: Impact of genetic polymorphisms in cytomegalovirus glycoprotein B on outcomes in solid-organ transplant recipients with cytomegalovirus disease. Clin Infect Dis 2009, 49:1160-1166.

46. Puchhammer-Stockl E, Gorzer I: Cytomelagovirus and Epstein-Barr virus subtypes the search for clinical significance. J Clin Virol 2006, 36:239-248.

47. Miller W, Flynn P, McCulbugh J, Balfour HH Jr, Goldman A, Haake R: Cytomegalovirus infection after bone marrow transplantation: an association with acute graft-vs-host disease. Blood 1986, 67:1162-1167.

48. Martino R, Rovira M, Carreras E, et al: Severe infections after allogeneic peripheral blood stem cell transplantation: a matched-pair comparison of unmanipulated and CD 34+ cell-selected transplantation. Haemat 2001, 86:1075-1086.

49. Ljungman P, Perez-Bercoff $L$, Jonsson J, et al: Risk factors for the development of cytomegalovirus disease after allogeneic stem cell transplantation. Haemat 2006, 91:78-83.

50. Cunha AA, Aquino VH, Mariquela V, Nogueira ML, Figueiredo LT: Evaluation of glycoprotein B genotype and load of CMV infecting blood leukocytes on prognosis of AIDS patients. Rev Inst Med Trop Sao Paulo 2011, 53:82-88.

51. Appleton AL, Sviland L: Pathogenesis of GVHD: role of herpes viruses. Bone Marrow Transpl 1993, 11:349-355.

\section{doi:10.1186/1471-2334-13-310}

Cite this article as: Dieamant et al:: Cytomegalovirus (CMV) genotype in allogeneic hematopoietic stem cell transplantation. BMC Infectious Diseases 2013 13:310.

\section{Submit your next manuscript to BioMed Central and take full advantage of:}

- Convenient online submission

- Thorough peer review

- No space constraints or color figure charges

- Immediate publication on acceptance

- Inclusion in PubMed, CAS, Scopus and Google Scholar

- Research which is freely available for redistribution 